\title{
The Origin of Diversity in Begonia: Genome Dynamism, Population Processes and Phylogenetic Patterns
}

\author{
A. Dewitte1, A.D. Twyford 2,3, D.C. Thomas'2,4, \\ C.A. Kidner 2,3 and J. Van Huylenbroeck ${ }^{5}$ \\ ${ }^{1}$ KATHO Catholic University College of Southwest Flanders, \\ Department of Health Care and Biotechnology \\ ${ }^{2}$ Royal Botanic Garden Edinburgh, 20A Inverleith Row, Edinburgh \\ ${ }^{3}$ Institute of Molecular Plant Sciences, University of Edinburgh, \\ King's Buildings, Edinburgh \\ ${ }^{4}$ University of Hong Kong, School of Biological Sciences, Pokfulam, \\ Hong Kong, \\ ${ }^{5}$ Institute for Agricultural and Fisheries Research (ILVO), \\ Plant Sciences Unit, \\ 1,5Belgium \\ 2,3 United Kingdom \\ ${ }^{4}$ PR China
}

\section{Introduction}

Species diversity is unequally distributed across the globe, with more species found in the tropics than any other ecosystem in the world. This latitudinal gradient of species richness illustrates the complex evolutionary history of global biodiversity, and many studies have placed it in the context of geological history and rates of speciation and extinction (Mittelbach et al., 2007). Historical biogeographic studies, using molecular phylogenies calibrated with a relative dimension of time, indicate that the accumulation of this diversity is both ancient ("museum" model) and recent ("cradle" model) within groups (Bermingham \& Dick, 2001; McKenna \& Farrell, 2006). An additional layer of complexity that makes it difficult to untangle the evolutionary processes driving tropical speciation are biotic interactions, such as plant competition and parasite interactions (Berenbaum \& Zangerl, 2006). Much of our understanding of the processes underlying speciation comes from mathematical models or studies of model organisms. However, some of the classical questions of evolutionary biology, such as what factors are driving speciation in species rich biomes, can only be understood by detailed evolutionary and ecological studies of specious groups.

Begonia is a genus of about 1550 described species, placing it in the top ten most speciose angiosperm genera (Frodin, 2004; Hughes, 2008). This makes it an ideal model for studying the processes and patterns underlying the generation of diversity (Forrest et al., 
2005; Neale et al., 2006). The distribution of Begonia diversity is uneven throughout tropical regions, with the greatest diversity in America and Asia ( $>600$ species each), whilst being relatively species poor in Africa (160 species) and absent in Australia (Goodall-Copestake et al., 2010). The genus is thought to have originated in Africa, while South American and South East Asian species are the results of parallel radiations over the last 20 - 50 million years (Goodall Copestake et al., 2010; Plana et al., 2004; Thomas et al., 2011). Long distance dispersal is rare, for example Begonia species have failed to cross the Torres strait from Papua New Guinea to Australia.

Begoniaceae are easily recognizable by diagnostic characters such as asymmetrical leaves, unisexual monoecious flowers, twisted-, papillose stigmas, and dry-, three-winged capsules (Doorenbos, 1998). However, there are numerous deviations from these typical character states. Within the genus Begonia there is a large range of morphological diversity, particularly in vegetative form, and this is linked to adaptation to a variety of ecological conditions. Vegetative adaptations such as the evolution of perennating rhizomes, leaf micromorphology optimised for low, scattered light; or stomatal clustering may underlie their ability to thrive in diverse niches. Phenotypic polymorphism within populations occurs, most frequently in the anthocyanin patterns on the leaves, which although striking have not been shown to have measurable effects on light capture (Hughes et al., 2008).

The genetic and morphological diversity of the genus Begonia has been exploited through cultivation to produce over 10,000 cultivars. These are horticulturally divided into 5 classes: a) the tuberous begonias (B. x tuberhybrida), a complex group derived from crosses between species such as $B$. boliviensis or $B$. pearcei, b) Elatior begonias (B. x hiemalis), a cross between tuberous begonias and B. socotrana, $\mathrm{c}$ ) Lorraine begonias (B. $\mathrm{x}$ cheimanta), a cross between tuberous hybrids and $B$. dregei, d) semperflorens begonias (B. semperflorens-cultorum), with $B$. cucullata and B. schmidtiana as important ancestors, and e) begonias grown for their ornamental foliage (B. rex-cultorum), Asiatic in origin (Haegeman, 1979; Hvoslef-Eide et al., 2007). Commercial interest in this group has promoted research into a variety of topics, including hybridisation and polyploidy.

Phylogenetic and cytological research in the last decade has significantly increased our knowledge of diversity within the genus Begonia. In this review, the current classification and the evolution of species diversity is discussed with reference to recent progress in: a) population genetic and phylogenetic techniques using genetic markers in association with morphological characters and b) cytological techniques such as mitotic or meiotic chromosome visualisation, linked to genome size studies. We also present new data on barriers to hybridisation between Begonia species. We focus on how genetic, cytological and local ecological effects may contribute to diversity in this genus, particularly the evolution of species diversity.

\section{Begonia classification}

Morphological and molecular data firmly place the Begoniaceae within the order Cucurbitales, which also includes the large and economically important family Cucurbitaceae (950-980 species), and the small families Anisophylleaceae (29-34 species), Apodanthaceae (19 species), Coriariaceae (15-20 species), Corynocarpaceae (5-6 species), Datiscaceae (2 species) and Tetramelaceae (2 species) (APG, 2009; Matthews \& Endress, 2004; Schaefer \& Renner, 2011; Zhang et al., 2006). Analyses of DNA sequence data from 14 
nuclear, mitochondrial and plastid markers strongly support a close relationship of Begoniaceae with Datiscaceae and Tetramelaceae (Schaefer \& Renner, 2011).

Only two genera are currently recognized in the Begoniaceae: the monotypic genus Hillebrandia, and the species-rich and morphologically diverse genus Begonia (Doorenbos et al., 1998; Forrest \& Hollingsworth, 2003). A third genus, Symbegonia, was previously included in Begoniaceae, and separated from Begonia by floral characters (syntepalous perianth and a monadelphous androecium). Based on molecular data, the genus Symbegonia has been shown to be nested within Begonia section Petermannia (Forrest \& Hollingsworth, 2003). Hillebrandia sandwicensis, which is endemic to Hawaii, can be differentiated from Begonia by a suite of morphological characters. These include more differentiated segments of the perianth, semi-inferior ovaries (inferior in Begonia), and fruit dehiscence between the styles in contrast to the usually loculicidal dehiscence in Begonia (Clement et al., 2004; Forrest \& Hollingsworth, 2003; Forrest et al., 2005).

A reliable infrageneric classification and subdivision of large genera such as Begonia is crucial in order to inform taxonomic monographs, biogeographic and evolutionary studies. A revision of circumscriptions of Begonia sections by Doorenbos et al. (1998) provides a foundation for the subdivision of the genus. In this revision 63 sections were recognized, and another three sections have been subsequently proposed (de Wilde \& Plana, 2003; Forrest \& Hollingsworth, 2003; Shui et al., 2002). The distributions of all but one of the currently accepted Begonia sections are limited to single continental regions, i.e. Africa, Asia, or America. Only section Tetraphila can be found in multiple continents and a single, recently discovered, and still to be named species in this predominantly African section is indigenous to continental Southeast Asia (de Wilde, 2011).

DNA sequence data from non-coding regions plays an important role in plant classification and barcoding (CBOL Plant working group, 2009), and has widely been used to resolve relationships at the species and sectional level in Begonia. A framework phylogeny of Begonia based on analyses of c. 13000 bases of plastid and mitochondrial DNA of 30 Begonia species (Goodall-Copestake et al., 2010; Fig. 1) indicates that African taxa form the earliest divergent clades in the Begonia phylogeny and that both Asian and American Begonia lineages are derived from African ancestors. The phylogenetic relationships within the relatively small group of African Begonia, which comprises around 160 species subdivided into 17 sections (de Wilde \& Plana, 2003; Doorenbos et al., 1998), are relatively well understood. African Begonia species are not retrieved as monophyletic, but South African species placed in section Augustia were shown to be closely related to a clade of American taxa, and Socotran Begonia species (section Peltaugustia) were shown to form a monophyletic clade with Asian taxa (Forrest et al., 2005; Goodall-Copestake et al., 2010; Plana et al., 2004; Thomas et al., 2011). Revisions exist for the majority of the African sections (see references in Plana, 2003), and the intersectional relationships of African Begonia species have been studied using molecular systematic approaches and have been discussed in some detail in Plana (2003) and Plana et al. (2004). Most African sections are well circumscribed and seem to represent monophyletic taxa, but section Mezierea is polyphyletic (Forrest et al., 2005; Plana, 2003; Plana et al., 2004); and the lack of resolution or support in phylogenies makes the assessment of the monophyly of some sections problematic. Apart from the grade of continental African taxa, a major Madagascan radiation can be detected. Only one of the c. 50 Madagascan (incl. Comores and Mascarenes) Begonia species, Begonia oxyloba, is also widespread on the African continent (Keraudren-Aymonin, 1983). The other Madagascan species seem to be the result of a single dispersal event from continental Africa and a subsequent radiation (Plana, 2003; Plana et al., 2004). 


\section{Chloroplast}

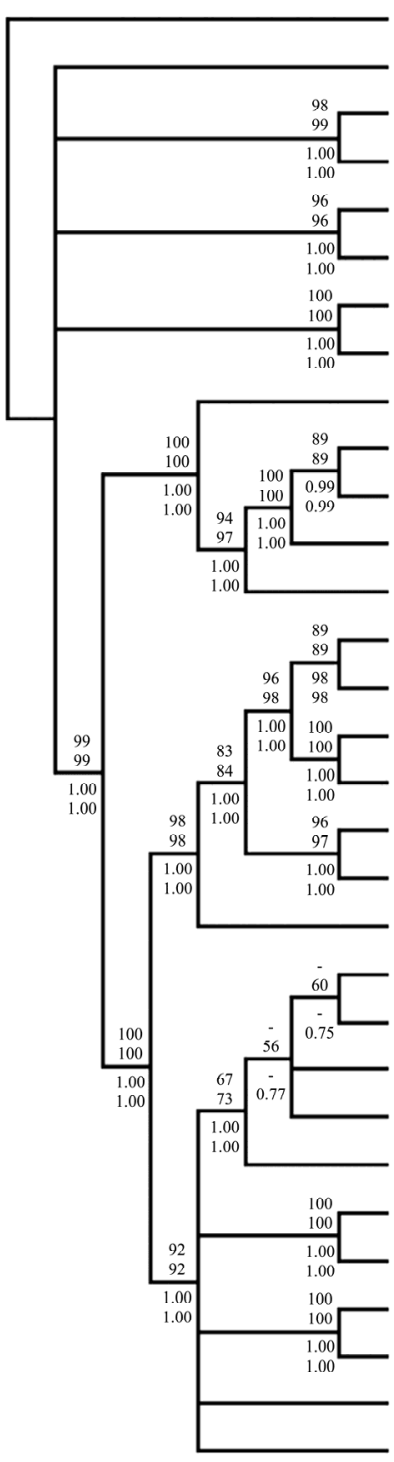

H. sandwicensis (Hawaii)

B. oxyloba (Tanzania)

B. bogneri (Madagascar)

B. goudotii (Madagascar)

B. thomeana (Sao Tome)

B. aspleniifolia (Gabon)

B. poculifera (Cameroon)

B. polygonoides (Ivory Coast)

B. johnstonii* (E Africa)

B. ulmifolia (Guyana \& Venezuela)

B. piurensis (Ecuador)

B. petasitifolia (Brazil)

B. macdufficana (Brazil)

B. herhacea (Brazil)

B. radicans (Brazil)

B. bissei (Culsa)

B. foliosa (Columbia)

B. nelumbiifolia (Mexico)

B. boliviensis (Boliva)

B. dregei $i^{\text {** (S Africa) }}$

B. chloroneura (Philippincs)

B. kingiana (Peninsular Malaysia)

B. symsanguinea (New Guinea)

B. amphioxus (Borneo)

B. morsei (China)

B. palmata (China)

B. robusta (Java)

B. floccifera (India)

B. malabarica (India \& Sri Lanka)

B. dipetala (India \& Sri Lanka)

B. socotrana* (Socotra)
Mitochondrion

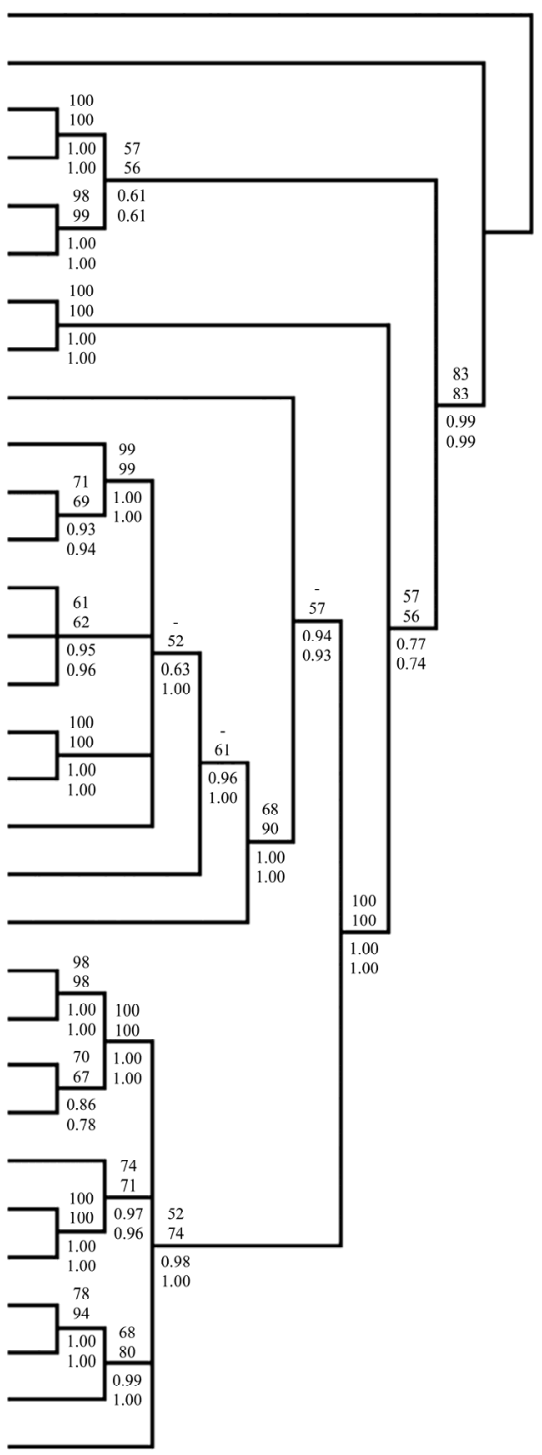

Fig. 1. Cladograms showing relationships supported by $\geq 50 \%$ parsimony bootstrap and $\geq 50 \%$ Bayesian posterior probability support after analysis of the genome-level DNA sequence datasets with indel data (Goodall-Copestake et al., 2010). The geographic origin of taxon samples is given in brackets and the African, American, and Asian continental species assemblages are indicated by pale, mid, and dark grey shading, respectively. Seasonallyadapted African Begonia species are indicated by asterisks. 
Asian and Socotran Begonia species form a well supported clade in recent analyses of nuclear, mitochondrial and plastid DNA sequence data (Goodall-Copestake et al., 2010; Thomas, 2010; Thomas et al., 201)). The c. 750 Asian Begonia species have been divided into 20 sections (Doorenbos et al., 1998; Forrest \& Hollingsworth, 2003; Shui et al., 2002; Thomas et al., 2011). However, the circumscriptions of several of these sections are questionable and phylogenetic analyses of sequence data provide evidence for the non-monophyly of most species-rich Asian sections (Forrest \& Hollingsworth, 2003; Tebbitt et al., 2006; Thomas, 2010; Thomas et al., 2011). Moreover, several small or monotypic sections were shown to be nested within clades of species assigned to the larger, species-rich sections. For example, section Baryandra is nested within Philippine Diploclinum (Rubite, 2010; Thomas, 2010); sections Alicida and Putzeysia fall into a grade of continental Asian species predominantly assigned to section Diploclinium (Rajbhandary, 2010; Thomas, 2010; Thomas et al., 2011); and section Monopteron is nested within section Platycentrum (Forrest, 2001; Rajbhandary, 2010; Thomas, 2010).

Within Asian Begonia two well supported major clades can be differentiated based on molecular data. The first is dominated by continental Asian taxa, and mainly includes species of section Parvibegonia, continental Asian species of the polyphyletic section Diploclinium, and species in sections Platycentrum and Sphenanthera. The second major clade contains the predominantly Chinese section Coelocentrum that forms the sister clade to a clade of Malesian species placed in sections Ridleyella, Bracteibegonia, Petermannia, and Malesian species placed in the polyphyletic sections Diploclinium and Reichenheimia (Thomas, 2010; Thomas et al., 2011).

American Begonia comprise more than 600 species divided into 29 sections (Burt-Utley, 1985; Doorenbos et al., 1998). American Begonia species are retrieved as monophyletic in analyses of nuclear ribosomal and mitochondrial DNA sequence data, but form two distinct clades with African sister groups in analyses of plastid DNA sequence data (Forrest \& Hollingsworth, 2003; Goodall-Copestake et al., 2010). This phylogenetic incongruence may indicate an ancient hybridisation event in this group (Goodall-Copestake et al., 2010). In contrast to African and Asian Begonia, the phylogenetics of American Begonia are still poorly understood, and the circumscriptions of several neotropical sections are highly problematic. Doorenbos et al. (1998: 181) emphasized that several neotropical sections "shade off into each other," i.e. sectional delimitations often lack autapomorphic characters and morphologically transitional species are present. Low-density taxon samples of 9-11 American species were included in the analyses by Clement et al. (2004), Forrest \& Hollingsworth (2003), Forrest et al. (2005) and Goodall-Copestake et al. (2010), but further studies including a much wider and geographically robust sampling of American Begonia species are needed to identify major subdivisions within American Begonia, clarify sectional delimitations and investigate intersectional relationships.

\section{Historical biogeography}

Molecular divergence age estimates based on DNA sequence data and the calibration of molecular changes with a dimension of time, allow inference of: i) the time of origin of monophyletic groups, and ii) the timing of dispersal to a geographic area (Renner, 2005). However, molecular divergence age estimates for clades of Begoniaceae is problematic, as the family has a poor fossil record, and suitable fossils for direct calibration are lacking 
(Stults \& Axsmith, 2011). Previous studies have addressed this problem by using island emergence dates as calibration points (Plana et al., 2004) or by putting Begoniaceae in a wider phylogenetic context using suitable fossils calibrations in related taxa (Clement et al., 2004; Goodall-Copestake, 2005; Goodall-Copestake et al., 2009; Thomas, 2010).

Most mean age estimates indicate an Eocene origin (c. 40-46 Ma) for the Begoniaceae crown group diversification (Clement et al., 2004; Goodall-Copestake, 2005; Plana et al., 2004; Thomas, 2010). However, there are considerable confidence intervals depending on the methods and calibration points used (Fig. 2). The geographic origin of Begoniaceae remains enigmatic, with the geographically isolated Hillebrandia in Hawaii and the disjunct distribution of the two species of the putative sister family Datiscaceae, in southwestern North America and southwestern Asia. Clement et al. (2004) hypothesized a widespread most recent common ancestor of Begoniaceae in Eurasia.

The mean age estimates for the Begonia crown group diversification indicate an Oligocene origin (c. 23-34 Ma), although large confidence ranges have to be considered (Fig. 2) (Goodall-Copestake et al., 2009; Thomas, 2010). The earliest divergent clades in the Begonia phylogeny are African, suggesting an early diversification on the African continent long after the Gondwanan break-up (Goodall-Copestake et al., 2010; Plana et al., 2004; Thomas, 2010). From Africa, Begonia dispersed independently to both America and Asia, and the early Miocene has been inferred as the most likely timeframe for these dispersal events (Goodall-Copestake, 2005; Goodall-Copestake et al., 2010). African Begonia species (sections Rostrobegonia, Sexalaria, Augustia and Peltaugustia), which are phylogenetically closely related to Asian and American Begonia lineages, show adaptations to seasonally drier climate. Goodall-Copestake et al. (2010) hypothesised that these drought adaptations made the ancestors of the American and Asian lineages more resilient to intercontinental dispersal than the vast majority of African species, which require moist and shaded habitats. Intercontinental dispersal likely occurred by long-distance dispersal, or alternatively, dispersal to Asia may have occurred by an overland dispersal route via the Arabian Peninsula during a more mesic period than at present (Goodall-Copestake, 2005; GoodallCopestake et al., 2010). The hypothesis of dispersal from Africa to western Asia is consistent with phylogenetic analyses and ancestral area reconstructions of Asian Begonia, which indicate an initial diversification of Asian-Socotran Begonia in South India-Sri Lanka, Socotra and continental Asia. This was followed by multiple dispersal events into Malesia, and a predominantly west to east colonisation of the Malesian archipelago (Thomas, 2010).

The relatively low species diversity of African Begonia (c. 160 species) in comparison to the species diversity in the New World (>600 species) and Asia (c. 750 species) may partly be explained by extinction of African Begonia species. This may be due to large-scale aridification during cooler and dry periods in Africa, especially during the pronounced climate oscillation in the Pleistocene. In addition to this, rapid diversifications in the Asian tropics and the Neotropics may explain the uneven distribution of Begonia diversity (de Wilde, 2011; Forrest et al., 2005; Thomas, 2010). Weakly developed mechanisms to maintain species cohesion in fragmented habitats (Hughes \& Hollingsworth, 2008), in association with the formation of topographical heterogeneity caused by mountain uplift from the early Pliocene onwards, may have been major drivers of rapid Begonia diversification in Southeast Asia (Thomas, 2010). Moreover, the diversification of Southeast Asian Begonia may have been accelerated by cycles of range fragmentation and amalgamation caused by Pleistocene climate and sea-level changes (Thomas, 2010). Cyclic vicariance due to climate oscillations and Pleistocene diversification have also been hypothesised for some species-rich African 
taxa such sections Loasibegonia and Scutobegonia (Plana et al., 2004; Sosef, 1994), but Plana et al. (2004) emphasised that a significant proportion of Begonia species diversity is of prePleistocene origin.

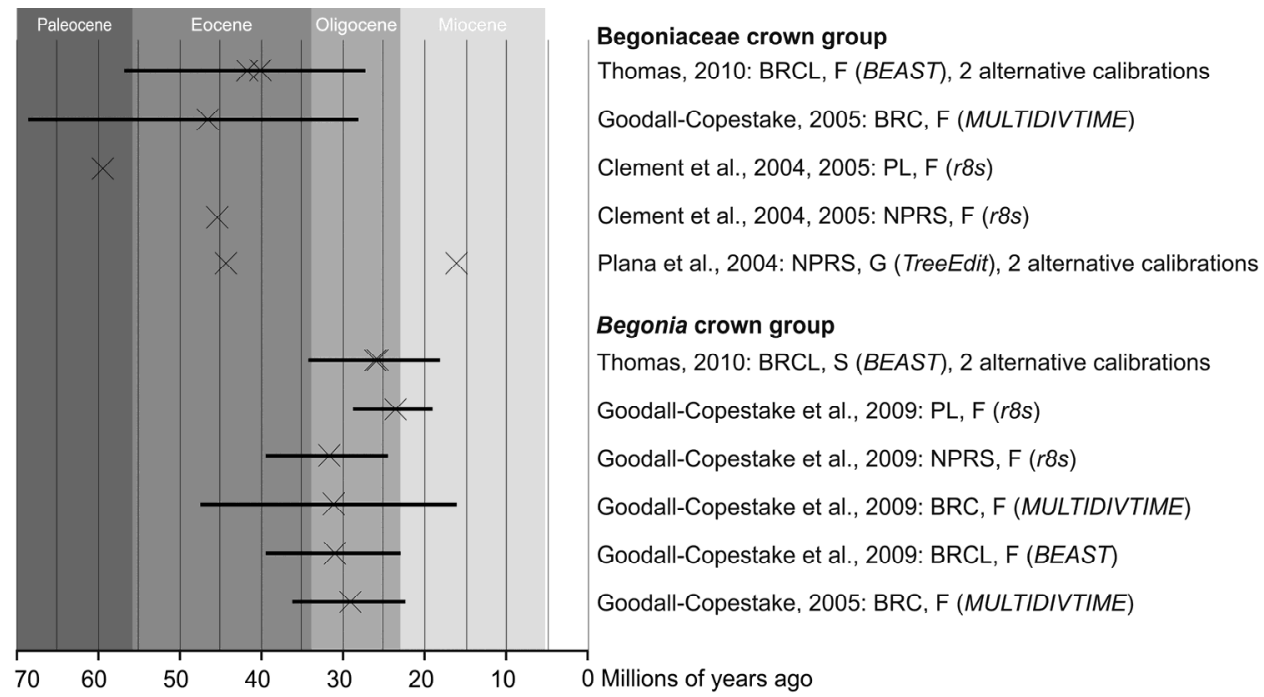

Fig. 2. Molecular divergence age estimates for the Begoniaceae and Begonia crown groups. Crosses indicate mean estimates, and bars indicate $95 \%$ highest posterior density age ranges and $95 \%$ confidence ranges. BRC: Bayesian auto-correlated rates relaxed clock method; BRCL: Bayesian uncorrelated rates relaxed molecular clock method assuming a lognormal distribution of rates; F: fossil calibration; G: geological calibration; NPRS: Non-Parametric Rate Smoothing method; PL: Penalized Likelihood method; S: secondary calibration. Software packages used are indicated in italics in brackets. For details of calibration regimes and methods see: Clement et al., 2004; Goodall-Copestake, 2005; Goodall-Copestake et al., 2009; Plana et al., 2004; Thomas, 2010.

\section{Population processes}

\subsection{Restricted gene flow}

Whilst the genus Begonia has a very broad distribution, differentiation occurs over very local scales (Hughes, 2008). Three studies have used molecular markers to study local patterns of differentiation. Matolweni et al. (2000) investigated allozyme variation in 12 populations of B. dregei and 7 populations of the closely related B. homonyma from isolated forest patches in South Africa. This data showed little, if any, gene flow among populations of either B. dregei or $B$. homonyma, even between populations that are located only a few kilometers apart within the same forest. Allelic variation and heterozygosity were low, alleles were frequently unique to individual populations, and population differentiation (Fst values) for each locus were very high. This suggests strong and longterm isolation between populations generating extensive genetic divergence and high potential for speciation.

A comparable study was performed by Hughes \& Hollingsworth (2008). Seven populations of the South African B. sutherlandii were sampled throughout the mist belt forests of 
Kwazulu-Natal, and population structure assessed using microsatellite markers. A similar population structure was observed to $B$. dregei and B. homonyma. Levels of population differentiation were high and there was significant differentiation between populations, even within subpopulations at a small spatial scale. The genetically isolated nature of $B$. sutherlandii populations suggest effective interpopulation dispersal is rare. There was no significant link between genetic and geographic distance suggesting that this differentiation is caused by genetic drift rather than through long-term isolation.

A third study of population structure in Begonia socotrana and B. samhaensis at the Socotra archipelago also shows the same pattern of strongly isolated populations (Hughes et al., 2003). The low intraspecific gene flow could be due to both poor seed dispersal in the sheltered conditions of the forest floor and to limited pollen flow. Begonia flowers do not attract specialist pollinators but practice deceit pollination by generalist pollinators such as small bees and flies. Analysis of this pollination mechanism in the wild has confirmed that it does results in a low seed set (Ågren \& Schemske, 1993; de Lange \& Bouman, 1999).

Isolation-by distance may contribute to speciation in the genus. As described by Hughes \& Hollingsworth (2008), the population-level data are congruent with the macro-evolutionary patterns observed in the genus. Molecular phylogenies confirm that Begonia is characterized by geographically constrained monophyly, species with narrow geographical ranges, very few widespread species, and high levels of morphological differentiation between populations of the few widespread species (Hughes \& Hollingsworth, 2008).

\subsection{Refuge Begonia}

The limited dispersal of many Begonia makes them a useful group to search for the biogeographic signature of refugia (Sosef, 1994). Refugia are regions where vulnerable lineages could survive periods of dramatic climate change, such as ice ages. When the climate becomes favorable again, species disperse outwards from the refugia. This generates a distinctive pattern in the geographic distribution of genetic diversity, with former refugia having greater genetic diversity. The poor dispersal of Begonia means regions with high numbers of Begonia species are possible former refugia. Species of the African sections Loasibegonia and Scutobegonia are restricted to humid and shady locations and are proposed to have been especially sensitive to the period of Pleistocene climate oscillations, and dispersed slowly afterwards (Sosef, 1994). Centers of diversity for these sections are situated in West and Central Africa. Plana et al. (2004) also used Begonia diversity to identify the island of Sao Tome as a pre-Pleistocene refuge, and suggested different mainland areas in West Africa as refuges. It is quite possible that a number of different refugia existed for lineages with different ecological tolerances.

\section{Cytological investigations and genome size comparisons}

Begonia exhibit a highly dynamic genome, with large variation in chromosome number, genome size and mean chromosome size as well as divergent chromosome structure, even between closely related species (Dewitte et al., 2009a). Traditionally, investigations at the chromosome level have been hindered by the small size of Begonia chromosomes, the difficulty in visualising centromeres, and few reliable karyograms. However, recent investigations using horticultural hybrids between divergent species, as well as cytological studies in the context of phylogenetic relationships, have greatly improved our understanding of this cytologically interesting genus. 


\subsection{Chromosome number}

The occurrence of particular chromosome numbers in a given group is important for predicting reproductive barriers between species and the potential fertility of the hybrids, and can be indicative of a close evolutionary relationship. Among Begonia species, chromosome numbers range from $2 n=16$ for $B$. rex to $2 n=156$ for B. acutifolia. Between these extremes, a wide range of chromosome numbers have been described (Doorenbos et al., 1998; Legro and Doorenbos, 1969; Legro and Doorenbos, 1971; Legro and Doorenbos, 1973). Many species or cultivars exhibit chromosome numbers of $2 n=26$ or 28 ( $x=13$ or 14 ) or a multiple of this number. Within the horticultural tuberous begonia group, derived from interspecific crosses between American Begonia, chromosome numbers of $2 n=27,28$ (diploid), 41,42 (triploid) and between 52 and 56 (tetraploid) are most common (Legro and Haegeman, 1971; Haegeman, 1979), but variation outside this sequence exists. In Asian Begonia, $2 n=22$ $(x=11)$ is the most frequently observed chromosome number. A phylogeny of non-coding cpDNA also indicates a base chromosome number of $x=15$ may be ancestral within Asian Begonia, with chromosome counts of 30 or 44 as diploid and triploid derivatives (Thomas, 2010; Thomas et al., in press).

The search for a basic chromosome number is complex as there is no common number observed in the group, even taking into account the prevalence of polyploidy in the horticutural varieties assayed. Some authors (Matsuura \& Okuno, 1936; Matsuura \& Okuno, 1943; Okuna \& Nagai, 1953; Okuna \& Nagai, 1954) have suggested $x=6, x=7$ and $x=13$ as the basic chromosome number, where $x=13$ may be of secondary origin. By using genomic in situ hybridisation (GISH), Marasek-Ciolakowska (2010) concluded that $x=7$ may be the basic chromosome number of $B$. socotrana. They based this conclusion on the presence of $7 B$. socotrana chromosomes and 56 chromosomes derived from tuberous Begonia in Elatior hybrids. An alternative explanation of the genomic composition of these Elatior hybrids is selective chromosome elimination of $B$. socotrana chromosomes after hybridisation. Selective chromosome elimination is a genome stabilisation process, and cytological investigation by Arends (1970) supports a role for it in the breeding of Elatior Begonia, observing 9 or $12 \mathrm{~B}$. socotrana chromosomes in some Elatior hybrids.

The inferred African origin for Begonia may suggest a basic chromosome number will be found in these taxa, especially early branching lineages. However it is uncertain how the genomic composition, particularly in terms of chromosome number, has changed in extant African species relative to their ancestors. Most of the described chromosome numbers in African taxa vary between 36 and 38, but counts of 22, 26 and 28 have also been made. Chromosome numbers of 22, 26 and 28 appear to be prevalent in the East-African seasonally adapted Begonia from the sections Rostrobegonia and Sexalaria, which diverged very early during Begonia evolution, and from the sections Augustia and Peltaugustia. These sections show a closer relationship to American and Asian sections than to other African sections.

The closely related Hillebrandia sandwichensis has a chromosome number of $2 n=48$ (Kapoor, 1966), probably the result of a polyploidisation of a 'diploid' with $2 \mathrm{n}=24$. Within the most related family Datiscaceae, $2 n=22$ is reported for Datisca cannabina (Gupta et al., 2009). The chromosome numbers within the family Cucurbitaceae are very diverse, but many species posses chromosome numbers between $2 n=20$ and 26 or multiples of these numbers, and $2 n$ $=14,16$ and 18 are also widely reported. In the Coriariaceae, multiples of 20 were observed $(2 \mathrm{n}=20,40$ and 60$)$ while in Corynocarpus, $2 \mathrm{n}=44$ or 46 is reported. An exact list of chromosome numbers and references in the abovementioned families is available at the TROPICOS ${ }^{\circledR}$ database (www.tropicos.org). These numbers indicate that basic chromosome 
numbers within these families are situated between $x=10$ and 13. However, within the basally branching family Anisophylleaceae, chromosome numbers of $x=7$ and $x=8$ are reported (Tobe \& Raven, 1987).

The above data suggest a diploid chromosome number for the genus Begonia between 20 and 26; chromosome numbers of $2 \mathrm{n}=36$ or 38 were probably established after polyploidisation and genome stabilisation early in the evolution of this genus. Given that the 'older' sections within the genus have a chromosome number of $2 n=26$, we suggest that $x=13$ is the original basic chromosome number, a chromosome number observed among sections across the world. However, it cannot be excluded that the basic chromosome number of $x=13$ is of secondary origin and arose from a fusion between cells with $x=6$ and 7 (as suggested by meiotic studies on B. evansiana by Okuna \& Nagai (1953)), although karyomorphological studies in Begonia do not support $x=6$ or 7 as basic chromosome number. If this was the case, the hybrid B276 $(2 n=50$; Dewitte et al., 2009a) would be a near octoploid and 8 homoeologous chromosomes should be identified, instead of the near tetraploid spread observed $(x=14)$. Further evidence from Oginuma \& Peng (2002) show $B$. palmata and $B$. aptera (both $2 \mathrm{n}=22$ ) have 2 secondary constriction chromosomes, which supports a basal number of $\mathrm{x}=11$ in Taiwanese Begonia.

Subsequently, chromosome numbers have diverged resulting in some 'new' basic chromosome numbers for some subgroups (eg $x=11$ or $x=14$ ), through selective chromosome elimination and polyploidy. Other derived numbers may have resulted from interspecific hybridisation, and Legro \& Doorenbos (1969) suggested that $2 n=22$ possibly originated out of a cross between $2 n=16$ and $2 n=28$.

\subsection{Chromosome structure}

Few studies have looked into changes in chromosome structure during Begonia evolution. Although karyomorphological data in Begonia are limited, many secondary constriction (SC) chromosomes have been detected. A SC chromosome consists of a satellite connected to the main body by the secondary constriction, a thin strip of the chromosome (Fig. 3). Oginuma \& Peng (2002) showed that up to $63 \%$ of the chromosomes in a cell can be secondary or tertiary constriction chromosomes. Moreover, all 14 species of Taiwanese Begonia (including B. palmata and B. aptera with $2 \mathrm{n}=22$ ) surveyed possessed SC, except for B. fenicis $(2 \mathrm{n}=26)$, where the exact position of centromeres could not be determined for some chromosomes. Dewitte et al. (2009a) observed SC chromosomes in 6 out of 11 genotypes investigated. During prophase, the satellites were so loosely associated to their main body that they could easily be misidentified as separate chromosomes. Additional evidence for SC chromosomes in Begonia was presented by Legro \& Doorenbos (1969).

These data suggest that after polyploidisation, chromosome translocations occur, which are followed by a decrease in chromosome number and genome stabilisation (Oginuma \& Peng, 2002).

\subsection{Chromosome size}

Flow cytometric measurements of genome size, combined with chromosome counts, revealed a 12-fold difference in the mean chromosome size between the species $B$. dietrichiana and B. pearcei (Dewitte et al., 2009a). Moreover, as only 15 of the 66 sections of the genus Begonia were involved in this study it is likely that greater differences will be found when other sections are surveyed. Differences in chromosome size have also been 
observed in horticultural hybrids, including Elatior hybrids that are characterized by small B. socotrana and large B. $x$ tuberhybrida chromosomes.

Apart from B. pearcei and B. boliviensis, South American species possess smaller chromosomes than Asian, African and Middle American species (Dewitte et al., 2009a). Different mechanisms, such as transposon activity, multiple deletions or other genetic rearrangements may have played an important role in the generation of this chromosome size variation (Devos et al., 2002; Kubis et al., 1998; Sanmiguel \& Bennetzen, 1998). Bennetzen (2002) showed that more than $60 \%$ of some plant genomes consist of transposable elements and their defunct remnants.

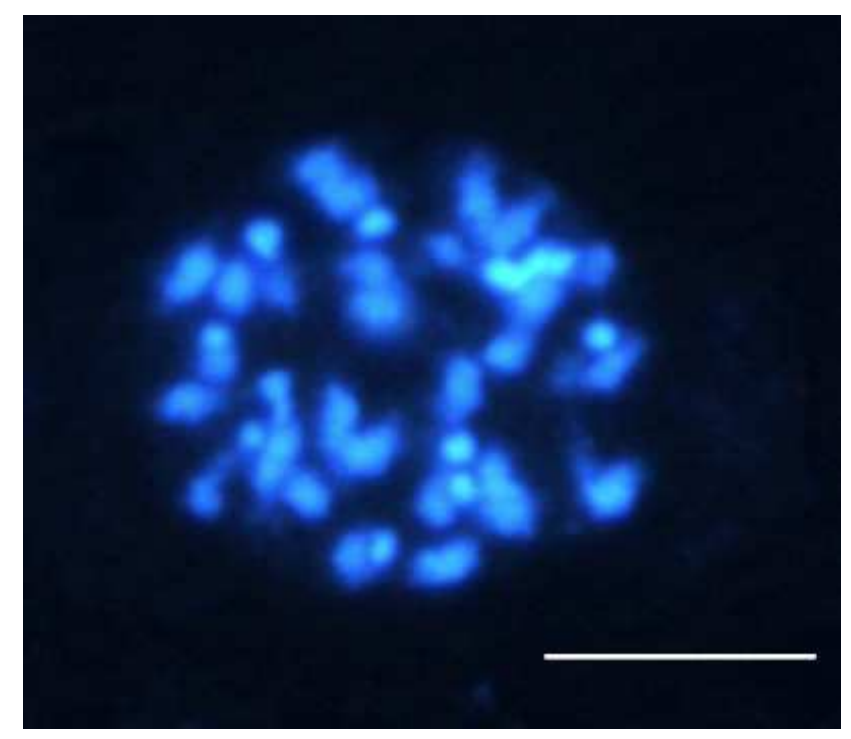

Fig. 3. Prometaphase mitotic chromosome spread of $B$. 'Tamo' $(2 \mathrm{n}=23)$, stained with DAPI. Intense fluorescence signal indicates satellites (Dewitte et al., 2009a). Bar $=5 \mu \mathrm{m}$.

\subsection{Polyploidisation}

Polyploidisation within Begonia may play a role in the diversification of lineages, the formation of new species, and morphological innovation. Evidence for the importance of polyploidy in Begonia evolution comes from the wide range of chromosome number, even in related species. Polyploids can arise by means of somatic mutations in meristematic cells or unreduced (2n) gametes (Bretagnolle \& Thompson, 1995; Otto \& Whitton, 2000). Harlan \& De Wet (1975) showed that many plant species produce $2 n$ gametes, and it is now generally accepted that $2 \mathrm{n}$ gametes are the driving force behind the formation of polyploids in nature (Bretagnolle \& Thompson, 1995). The occurrence of $2 \mathrm{n}$ gametes in a Begonia collection has been described by Dewitte et al. (2009b), where 10 of the 70 investigated genotypes (collections of both species and cultivars) produced $2 \mathrm{n}$ pollen. The unreduced pollen grains were able to germinate and could be used to produce progeny. The occurrence of $2 \mathrm{n}$ egg cells was not investigated, but ploidy analysis of the progeny proved that $2 \mathrm{n}$ egg cells do 
occur (Dewitte et al., 2010a). Unreduced egg cells have also been observed in the hybrid $B$. cucullata $\times$ B. schmidtiana during breeding of semperflorens Begonia (Dewitte et al., 2010a; Horn, 2004).

Unreduced gametes have been shown to occur in species as well as hybrids (Dewitte et al., 2010a; Dewitte et al., 2009b). This suggests natural polyploid lineages may occur at a low frequency in the wild. However, hybrids may produce $2 \mathrm{n}$ gametes at c. 50 times higher frequency than species (Ramsey \& Schemske, 1998). In horticulture, interspecific hybrids are often a source of $2 n$ gametes. These $2 n$ gametes can transfer high levels of heterozygosity (Bretagnolle \& Thompson, 1995; Ramanna \& Jacobsen, 2003), promoting polyploid establishment, and in some cases $2 \mathrm{n}$ gametes may be the only viable gametes in hybrids (Barba-Gonzalez et al., 2004; Dewitte et al., 2010b).

\subsection{Genome size variation}

The combined effect of polyploidy and genome stabilisation is a highly variable genome size across the genus. By using flow cytometry, Dewitte et al. (2009a) observed variation in genome size between $1 \mathrm{C}=0.23 \mathrm{pg}$ and $1.46 \mathrm{pg}$, but genome size did not positively correlate with chromosome number. The largest known discrepancies between genome size and chromosome number were observed in B. pearcei and B. boliviensis, which have the largest genome size measured in Begonia to date $(1 \mathrm{C}=1.46 \mathrm{pg})$, although they contain the lowest chromosome number of all genotypes analysed $(2 n=26$ and 28 , respectively). The lack of correlation between genome size and chromosome number can be explained by the strong differences in chromosome size. Dewitte et al. (2009a) showed that the total chromosome volume in a cell was positively correlated to the genome size. Smaller chromosomes contribute less to the genome size than large chromosome do, even if the number of chromosomes is equal.

\subsection{Meiosis}

Chromosome pairing at metaphase I can indicate whether plants are diploids or secondary polyploids (autopolyploid or allopolyploid), but few cytological studies have focused on meiosis in Begonia. In B. evansiana (Okuna \& Nagai, 1953) and B. $x$ chungii (Peng \& Ku, 2009), several loosely associated bivalents (paired chromosomes), which almost resemble univalents (unpaired chromosomes), were observed during chromosome pairing. Furthermore, many secondary associations between bivalents were observed in B. evansiana (Okuna \& Nagai, 1953), consistent with observations in B. semperflorens and B. rex (Matsuura \& Okuno, 1943). These observations suggested B. evansiana is a secondary polyploid, derived from two species with $\mathrm{X}=6$ and 7 as their basic chromosome numbers.

In horticultural crosses, the interspecific hybrid $B$. 'Tamo' $(2 n=23)$ showed irregular chromosome pairing with multivalents of up to 7 chromosomes (Dewitte et al., 2010c). These associations were often observed between chromosomes with large differences in size, which indicated associations between non-homologous chromosomes and possible recombination between these non-homologous DNA segments (illegitimate recombination). Illegitimate recombination is the driving force behind genome size decrease in Arabidopsis (Bennetzen et al., 2005; Devos et al., 2002), but can also be an important mechanism for exon shuffling, a major process for generating new genes (Long, 2001; Long et al., 2003).

In some hybrids, tight associations between chromosomes resulted in chromosome bridges and fragments during anaphase I (Dewitte et al., 2010c). This might be indirect evidence for 
the presence of paracentric inversions during crossing-over (Newman, 1966). Paracentric inversion loops are crossing over configurations that result in abnormal meiotic end products such as dicentric chromosomes (with 2 centromeres) and acentric (without centromere) fragments. Consequently, new chromosome constitutions may arise during meiosis. Furthermore, chromosome inversions may affect rates of adaptation and speciation because it promotes reproductive isolation of species (Noor et al., 2001; Hoffmann \& Rieseberg, 2008). However, the importance of inversions in adaptive evolution has rarely been addressed and therefore its role in adaptive shifts is not yet clear.

Univalent formation was frequently observed in Begonia (Dewitte et al., 2010; Okuna \& Nagai, 1953). The presence of these univalents resulted in lagging chromosomes: chromosomes with a delayed movement to the poles. In some cases (dependent on the hybrid), univalents did not migrate to the poles but formed micronuclei. Although this usually leads to unbalanced chromosome segregation and sterility (Bretagnolle \& Thompson, 1995), most of the studied hybrids were fertile. It is uncertain to what degree Begonia are 'buffered' against unbalanced chromosome segregation. If the resulting aneuploid gametes are fertile, this process may influence the chromosome number transmitted through the progeny and the genome stabilisation process. However, more detailed studies on this topic are required.

In general, cytological studies (mainly in artificial hybrids) have shown that chromosome behaviour during meiosis is very dynamic which may have important consequences for chromosome evolution within the genus. However, further clarification with molecular evidence is required.

\section{Hybridisation}

Hybridisation and polyploidisation have played a major role in the evolution of plant species, and the stabilisation of hybrid lineages may contribute to species diversity (Mallet, 2007; Paun et al., 2009; Rieseberg \& Carney, 1998). However, estimating the frequency of hybrid speciation is difficult, as evidence that hybridisation has let to speciation is hard to obtain, particularly in homoploid hybrids (hybrids without a change in ploidy level) (Mallet, 2007). The role that hybridisation has played in contributing new lineages in diverse tropical biomes has yet to be addressed in detail (with some exceptions such as neotropical orchids, eg Pinheiro et al., 2010), however hybrid speciation may be one of the factors contributing to species diversity in large genera such as Begonia. Support for hybridisation and introgression being a mechanism for the generation of diversity would require an understanding of the strength of reproductive isolation between parental species, including factors such as the fertility of hybrids, and few studies have focused on this in Begonia.

Several natural Begonia hybrids have been described including: B. $x$ breviscapa, B. $x$ chungii and B. $x$ taipeiensis (Peng \& Ku, 2009; Peng \& Sue, 2000; Peng et al., 2010). This illustrates weak reproductive barriers between Begonia species that co-occur in the wild, which is typical of a genus that has been widely exploited in the development of horticultural varieties (Tebbitt, 2005). However, in most cases the number of species that co-occur at a single locality in Begonia is low. The ease of hybridisation under experimental conditions, combined with the low frequency of hybrid occurrence in the wild, indicates that habitat specialisation and non-overlapping geographic distributions may be important in maintaining the distinct identities of Begonia species. 
Natural hybrids of recent origin can often be recognised by low pollen fertility, however fertile Begonia hybrids have also been observed (B. decora x B. venusta, Kiew et al., 2003; Teo \& Kiew, 1999). The fertility of Begonia hybrids varies, and low hybrid fertility is likely to be due to genome divergence and incompatibilities between the progenitors. However, if F1 hybrids retain a low level of fertility then there is an opportunity for backcross progeny to be formed. Even if natural hybrids can be observed, further evidence is required to support the establishment of new hybrid species over time. For hybrid species to become established, they must become reproductively isolated from the parental species. Recent hybrids are likely to be swamped by well adapted parental species, however novel genetic combinations and the resulting heterosis (hybrid vigour) may explain their establishment (Lippman \& Zamir, 2007; Paun et al., 2009)

Allopolyploid speciation, where hybridisation is combined with polyploidisation, offers a likely path to speciation, because the hybrid will have a high degree of post-zygotic reproductive isolation from their progenitors (Paun et al., 2009), due to the low fertility of triploid plants. Polyploid plants have a number of notable changes relative to their progenitors, including increased cell size, gene dosage effects, increased allelic diversity (level of heterozygosity), gene silencing and genetic or epigenetic interactions (Leitch \& Bennett, 1997; Levin, 1983; Lewis, 1980; Osborn et al., 2003). The occurrence of viable unreduced gametes in Begonia hybrids has been described earlier, which is an important precursor for allopolyploid formation. Once polyploids are formed and established, they may enter an evolutionary trajectory of diploidization, a gradual conversion to diploidy through genetic changes that differentiate duplicated loci (Comai, 2005; Levy \& Feldman, 2002).

To understand the potential role of hybridisation in Begonia evolution, we performed a series of cross-fertilization experiments. Firstly, the effects of parental ploidy level, genome size and geographic origin on seedling viability and fertility was investigated. This experiment allowed us to compare the effects of hybridizing species with highly differentiated genomes, and to understand the role of polyploidy and genome size changes in reproductive isolation in Begonia. Secondly, we investigated the cross compatibility of more closely related species (from the Central American Section Gireoudia), in order to assess the likelihood that hybridisation may occur between species with less differentiated genomes that are more likely to co-occur in the wild.

In the first experiment, we cross hybridised 19 mainly South-American Begonia species (Table 1). From the 156 cross combinations performed, pollinating 5 flowers per cross, 27 combinations generated viable hybrids (Table 2). Successful crosses were observed between species with different chromosome numbers and genome sizes (e.g. B. cucullata $2 n=34,1 \mathrm{C}=$ $30 \times B$. odorata $2 \mathrm{n}=52,1 \mathrm{C}=0.56 \mathrm{pg}$ ), and even between species from different continents (e.g. B. dregei x B. coccinea; B. pearcei $\times$ B. grandis).

The likelihood that F1 hybrids were obtained increased when the species used for crossing came from the same section (Gaerdtia, Begonia), although this was not the case for the section Pritzelia. For example, within the section Begonia, B. cucullata, B. subvillosa var. leptotricha and $B$. schmidtiana had equal chromosome numbers $(2 n=34)$, while $B$. odorata contained a higher chromosome number $(2 \mathrm{n}=52)$. The genome sizes of $B$. cucullata and B. subvillosa var. leptotricha were similar (about $0.30 \mathrm{pg}$ ), but lower compared to those of B. schmidtiana (0.38 $\mathrm{pg})$ and B. odorata $(0.56 \mathrm{pg})$. Another species from the section Begonia, B. venosa $(2 \mathrm{n}=30 ; 1 \mathrm{C}$ $=0.25 \mathrm{pg}$ ), did not cross with these species. 


\begin{tabular}{lllll}
\hline & origin & section & Genome size & $\begin{array}{l}\text { Chromosome } \\
\text { number (2n) }\end{array}$ \\
\hline B. listada & America & Pritzelia & 0.31 & 56 \\
B. echinosepala var. elongatifolia & America & Pritzelia & 0.32 & 56 \\
B. coccinea & America & Pritzelia & 0.56 & 56 \\
B. corallina & America & Gaerdtia & 0.78 & 56 \\
B. albo-picta & America & Gaerdtia & 0.58 & 56 \\
B. solananthera & America & Solananthera & 0.57 & 56 \\
B. luxurians var. ziesenhenne & America & Scheidweileria & 0.32 & 56 \\
B. odorata & America & Begonia & 0.56 & 52 \\
B. subvillosa var. leptotricha & America & Begonia & 0.29 & 34 \\
B. cucullata & America & Begonia & 0.30 & 34 \\
B. schmidtiana & America & Begonia & 0.38 & 34 \\
B. venosa & America & Begonia & 0.25 & 30 \\
B. ulmifolia & America & Donaldia & 0.25 & 30 \\
B. heracleifolia & America & Gireoudia & 0.75 & 28 \\
B. boliviensis & America & Barya & 1.46 & 28 \\
B. pearcei & America & Eupetalum & 1.46 & 26 \\
B. dregei & Africa & Augustia & 0.66 & 26 \\
B. grandis var. evansiana & Asia & Diploclinium & 0.68 & 26 \\
B. diadema & Asia & Platycentrum & 0.58 & 22 \\
\hline Table 1. Origin, classification & gen & & \\
\hline
\end{tabular}

Table 1. Origin, classification, genome size and chromosome numbers of Begonia species used in the first experiment (classification from Dewitte et al., 2009).

These results suggest post-pollination barriers to hybrid formation in Begonia are complex, as no strong trend can be seen between parental genome size, chromosome number and the area of origin in the likelihood that F1 hybrids can be obtained. This is in agreement with the many horticultural interspecific crosses described (Tebbitt, 2005).

To assess the fertility of the hybrids, 5 to 10 of the F1 hybrid progeny were scored for pollen morphology and germination according to Dewitte et al. (2009b). The majority of hybrids examined were male sterile and either dropped their male flowers before opening or produced inviable pollengrains. Only a few combinations, mainly those between $B$. albopicta, B. corallina and B. coccinea, were male fertile (Table 3). They are all South American species with $2 \mathrm{n}=56$. B. albo-picta and B. corallina belong to the section Gaerdtia while B. coccinea belongs to the section Pritzelia. However, $B$. coccinea is morphologically very similar to $B$. corallina and their sectional affinities may require reappraisal.

In the second experiment, 12 species from the Central American section Gireoudia were crossed over a four year period (2005-2009) to investigate the cross compatibility of more closely related species. Of the 144 potential combinations between the parents, $92(64 \%)$ have been attempted - the other combinations did not overlap in their flowering time. Of the 92 combinations attempted, 89 (97\%) produced plump seeds, with little or no variability in success between repeats of the same cross. Only a single cross has failed to produce F1 
seeds in both directions (B. theimei $x$. heracleifolia) and two crosses have failed in one direction only (B. peltata $x$ B. serioceneura, B. nelumbiifolia $x$ B. heracleifolia). However, these are based on a single parental accession and few replicates, and this requires further crosses to confirm this result. Overall, the ability to form F1 hybrids between related Begonia species with the same chromosome number $(2 n=28$; the common chromosome number in this section), further supports weak postzygotic reproductive isolating barriers, as shown in Figure 4 .

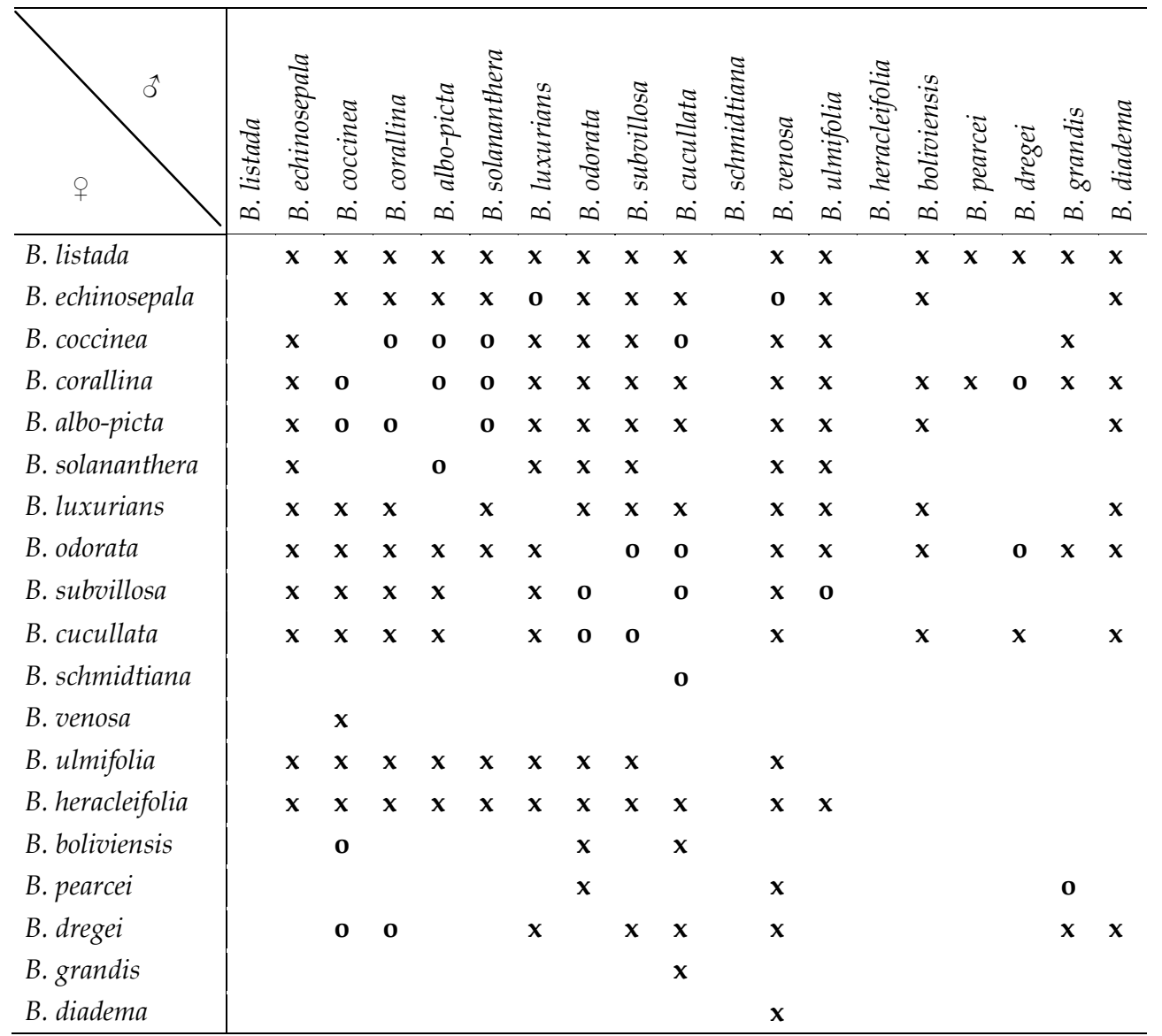

Table 2. Outcomes of interspecific crosses. Combinations resulting in viable hybrid are

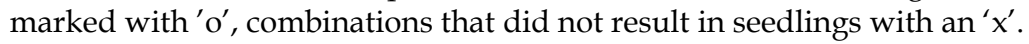

We then germinated the seeds from each seed capsule, to test for evidence of seedling mortality and the fertility of the hybrids. No evidence of seedling mortality was observed, that would indicate incompatible genome interactions which affect fitness at early growth stages (hybrid dysgenesis). Successful crosses were grown to maturity, and the 19 F1 hybrids that flowered in the Spring 2009 were scored for pollen viability. For each accession 100 pollen grains were stained with fluorescein diacetate (FDA) in 5\% sucrose solution, and 
The Origin of Diversity in Begonia:

percentage of well stained pollen scored. The mean pollen viability was $3.5 \%( \pm 1.9 \%)$, and $73 \%$ of hybrids were pollen sterile.

\begin{tabular}{|c|c|c|c|}
\hline \multicolumn{2}{|c|}{ cross } & \multirow{2}{*}{$\begin{array}{c}\% \text { bad, shrunken } \\
\text { pollen grains }\end{array}$} & \multirow{2}{*}{$\%$ germination } \\
\hline q & $\hat{0}$ & & \\
\hline B. albo-picta & B. corallina & $7,6 \pm 2,9$ & $48,4 \pm 21,0$ \\
\hline B. albo-picta & B. coccinea & $4,5 \pm 3,7$ & $39,6 \pm 28,5$ \\
\hline B. coccinea & B. albo-picta & $8,0 \pm 5,2$ & $45,3 \pm 20,0$ \\
\hline B. coccinea & B. corallina & $15,0 \pm 6,5$ & $41,5 \pm 17,6$ \\
\hline B. corallina & B. coccinea & $13,0 \pm 6,9$ & $50,0 \pm 36,7$ \\
\hline B. corallina & B. albo-picta & $18,8 \pm 6,5$ & $38,5 \pm 15,4$ \\
\hline B. echinosepala & B. luxurians & $98,6 \pm 0,6$ & $0,4 \pm 0,3$ \\
\hline
\end{tabular}

Table 3. Pollen fertility of fertile F1 hybrid combinations (means \pm SD; $n=5$ ). Only combinations producing male fertile progeny are included.

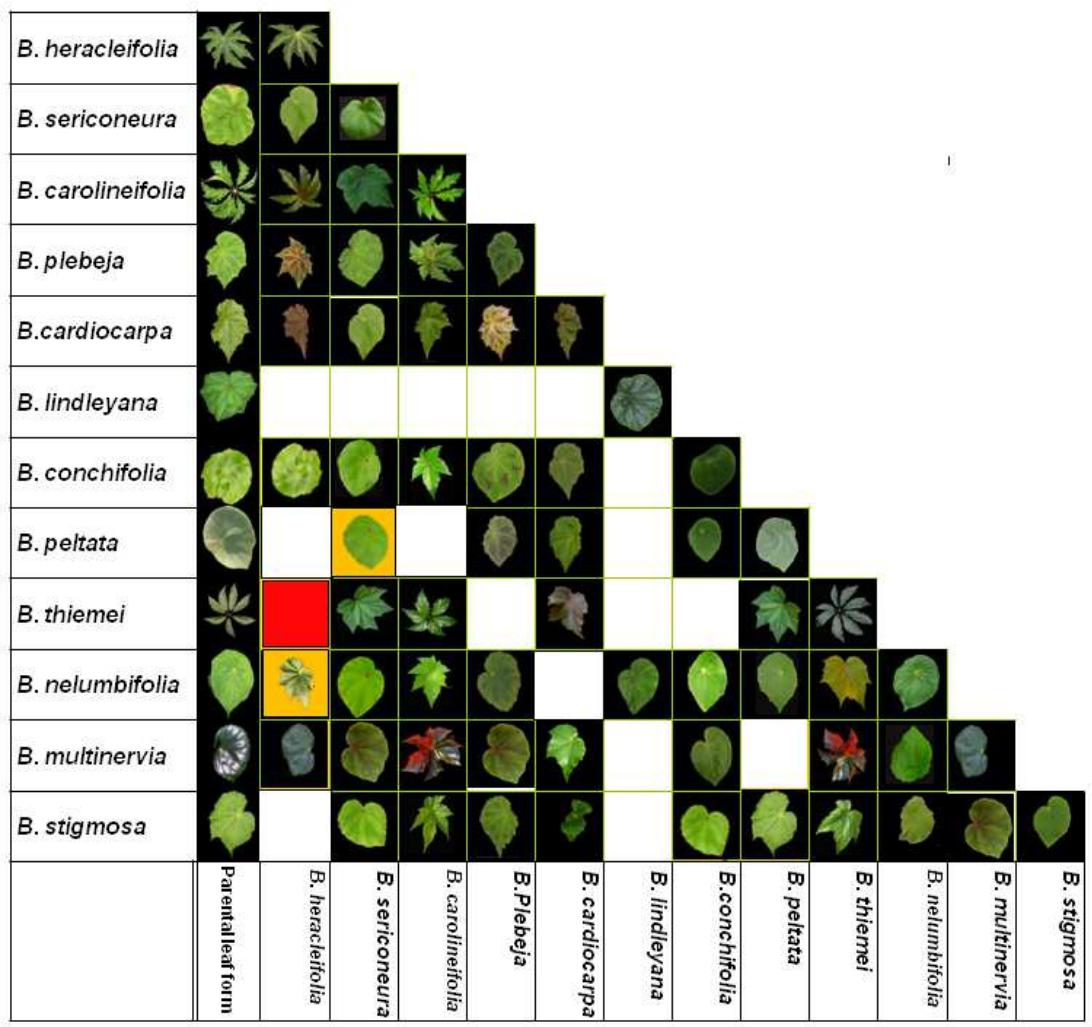

Fig. 4. Interspecific crossing barriers in the section Gireoudia. Leaves on a dark background indicate a successful F1 cross. A red square indicates an unsuccessful cross and a yellow background a cross that has worked in one direction only (Twyford \& Kidner, previously unpublished data). 
These results highlight that interspecific Begonia crosses have a significantly reduced pollen fertility. There are a number of notable exceptions, particularly in F1 crosses in the section Gireoudia, where pollen stainability is above 30\% (Matthews, unpublished). This includes crosses between divergent species found in different geographical areas, such as $B$. conchifolia and B. plebeja. Hybrids with good pollen fertility were also observed in section Gaerdtia (see above). Overall, this suggests that hybrid fertility is constraining in the formation of later generation hybrids in the wild. However, male fertility is not necessarily linked to female fertility as different genes may underlie male and female meiosis. Some of the male sterile hybrids have been successfully used as a seed parent in crosses (Dewitte et al., 2010a; Twyford \& Kidner unpublished data).

The role of hybrid speciation in Begonia should be investigated further, but several preconditions for hybrid speciation are fulfilled in this genus: weak crossing barriers, a very labile genome, the presence of natural interspecific hybrids and the occurrence of $2 \mathrm{n}$ gametes. The fertility of artificial hybrids is very variable and depends on the cross combination. If a hybrid retains some fertility and becomes isolated from its parent plant, hybrid speciation may be a possible outcome.

\section{Future perspectives and conclusions}

Begonia is a remarkable genus both for its size and diversity. As a pantropical genus, it provides the opportunity to compare biogeographic patterns in different regions using like to like. It also offers the chance to examine the reasons behind the high levels of tropical diversity through comparisons with speciation patterns in correspondingly widespread temperate genera.

Major progress has been made clarifying the evolutionary relationships in the genus Begonia at the sectional level. Further work is required at the species level, to assess lower level relationships, and reveal biogeographic patterns. The lack of a fossil record for the genus has been a stumbling block to the generation of detailed evolutionary scenarios (GoodallCopestake et al., 2009). Moreover, more informative genetic markers are needed to obtain well-resolved phylogenies of the recent rapid radiations that have occurred in different regions.. However, the development of barcoded next generation sequencing techniques holds out the promise that phylogenies of many hundreds of accessions could be produced en-mass, transforming our ability to detect speciation patterns. The decreasing cost of sequencing means that transcriptomes, whole plastid genomes and even draft nuclear genomes can be produced for reasonable amounts of money (Ng \& Kirkness, 2010).

The prevalence of geographic isolation between Begonia species may be one of the factors explaining the limited postzygotic reproductive isolating barriers between species. The lack of interspecific crossing barriers has contributed to its success as a horticultural subject, and provides us with the opportunity to use classical and quantitative genetic techniques to study the genes that vary between species.

On one level such analysis can be done by transcriptome or genome comparisons and the screening for genes that show the signature of diversifying or purifying selection (Biswas \& Akey, 2006). However, these techniques can provide only statistical support for the importance of any one locus, and are not informative about which traits are affected. In a non-model group the link between locus and function can only be based on comparisons with model species which may be misleading. 
A second approach works in the other direction, from the trait down to the locus. Once a genetic map has been constructed, quantitative trait locus (QTL) analysis can reveal the genetic architecture of species level differences: the number of loci that affect a trait, along with their sizes and interactions (Zeng, 2005). The traits most divergent between species may be related to the selective forces that drove speciation and can be linked to plant fitness as measured by seed production or to relative growth rate (Taylor et al., 2009). An ideal experiment would combine both approaches, mapping highly divergent genes relative to QTLs.

One of the great advantages of Begonia for this work is the parallel evolution that is common in the genus on many levels. Given sufficient genetic resources, comparisons can be made between the genetic architecture of traits independently evolved within and between sections and continents. This allows hypothesises about trait evolution to be tested using multiple replicates, providing greater robustness than is usually possible for evolutionary studies.

One topic that has yet to be studied in depth and deserves further attention is natural hybridisation and hybrid speciation. Hybrid speciation seems very likely within the genus, and interspecific processes may be the cause of the hard incongruence of phylogenetic trees derived from plastid and nuclear ribosomal data within some species-rich sections (Platycentrum, Petermannia) (Goodall-Copestake (2010), Thomas (2010). However, homoploid hybrids are hard to detect; and only a handful of species in evolutionary model systems have proven to be hybrids without a change in ploidy level (e.g. Helianthus, Argyranthemum, Ceanotus, Pinus (listed in Gross \& Rieseberg, 2005). Investigation of the frequency of natural hybridisation, together with studies of genome stabilisation after polyploidisation and more karyomorphological data may be useful to understand chromosome evolution within the genus. The use of molecular techniques, such as comparative transcriptional profiling or targeted genome resequencing of species and their hybrids (see Twyford \& Ennos, 2011), or cytological techniques such as GISH, may shed light on the role of natural hybridisation.

The genus Begonia has been studied for many reasons, including: horticulture, taxonomy, as an indicator for biogeographic variation, to understand the development of their distinctive leaf forms and their aberrations, population genetics of endemic species, hybridisation and genome dynamics. As the distinction between model plants with extensive genetic resources, and non-models without these resources becomes less well defined, we expect that Begonia will continue to provide insights into the nature and origin of tropical plant diversity.

\section{References}

Ågren, J. \& Schemske, DW. (1993). Outcrossing rate and inbreeding depression in two annual monoecious herbs, Begonia hirsuta and B. semiovata. Evolution, Vol.47, No.1, (February 1993), pp. 125-135, ISSN 1558-5646

APG (2009). An update of the Angiosperm Phylogeny Group classification for the orders and families of flowering plants: APG III. Botanical Journal of the Linnean Society, Vol.161, No.2, (October 2009), pp. 105-121, ISSN 0024-4074

Arends, JC. (1970). Somatic chromosome numbers in 'Elatior'-Begonias. Mededelingen Landbouwhogeschool Wageningen, Vol.70, No.20, pp. 1-18, ISSN 0369-0598 
Barba-Gonzalez, R.; Lokker, AC.; Lim, K-B.; Ramanna, MS. \& Van Tuyl, JM. (2004). Use of $2 \mathrm{n}$ gametes for the production of sexual polyploids from sterile Oriental $\times$ Asiatic hybrids of lilies (Lilium). Theoretical and Applied Genetics, Vol.109, No.6, (October 2004), pp. 1125-1132, ISSN 0040-5752

Bennetzen, JL. (2002). Mechanisms and rates of genome expansion and contraction in flowering plants. Genetica, Vol.115, No.1, (May 2002), pp. 29-36, ISSN 0016-6707

Bennetzen, JL.; Ma, J. \& Devos, KM. (2005). Mechanisms of recent genome variation in flowering plants. Annals of Botany, Vol.95, No.1, (january 2002), pp. 127-132, ISSN 0305-7364

Berenbaum, R. \& Zangerl, AR. (2006). Parnsnip webworms and host plants at home and abroad: trophic complexity in geographic mosaic. Ecology, Vol.87, No.12, (December 2006), pp. 3070-3081, ISSN 0012-9658

Bermingham, E. \& Dick, C. (2001). The Inga--Newcomer or Museum Antiquity? Science, Vol.293, No.5538, (September 2001), pp. 2214-2216, ISSN 0036-8075

Biswas, S. \& Akey, JM. (2006). Genomic insights into positive selection. Trends in Genetics, Vol.22, No.8, (August 2006), pp. 437-446, ISSN 0168-9525

Bouman, F. \& de Lange, A. (1983). Structure, micromorphology of Begonia seeds. The Begonian, Vol.50, (May 1983), pp. 70-78, 91

Bretagnolle, F. \& Thompson, JD. (1995). Gametes with the somatic chromosome number: mechanisms of their formation and role in the evolution of autoploid plants. New Phytologist, Vol.129, No.1, (Januari 2005), pp. 1-22, ISSN 0028-646X

Burt-Utley, K. (1985). A revision of the Central-American species of Begonia section Gireoudia (Begoniaceae). Tulane Studies in Zoology and Botany, Vol.25, No.1, pp. 1-131, ISSN 0082-6782

CBOL Plant working group (2009). A DNA barcode for land plants. Proceedings of the National Academy of Sciences, Vol.106, No.31, (August 2009), pp. 12794-12797, ISSN 0027-8424

Chen, ZJ. (2007). Genetic and epigenetic mechanisms for gene expression and phenotypic variation in plant polyploids. Annual Review of Plant Biology, Vol.58, (June 2007), pp. 377-406, ISSN 1543-5008

Clement, WL.; Tebbitt, MC.; Forrest, LL.; Blair, JE.; Brouillet, L.; Eriksson, T. \& Swensen, SM. (2004). Phylogenetic position and biogeography of Hillebrandia sandwicensis (Begoniaceae): a rare Hawaiian relict. American Journal of Botany, Vol.91, No.6, (June 2004), pp. 905-917, ISSN 0002-9122

Comai, L. (2005). The advantages and disadvantages of being polyploid. Nature Reviews Genetics, Vol.6, No.11, (November 2005), pp. 836-846, ISSN 1471-0056

de Lange, A. \& Bouman, F. (1999). Seed micromorphology of neotropical Begonias. Smithsonian Contributions to Botany, Vol. 90, (September 1999), pp. 1-49, ISSN 0081024X

de Wilde, JJFE. \& Plana, V. (2003). A new section of Begonia (Begoniaceae) from west central Africa. Edinburgh Journal of Botany, Vol.60, No.2, (October 2003), pp. 121-130, ISSN 0960-4286

de Wilde, JJFE. (2011). Begoniaceae. In: Familes and Genera of Vascular Plants (Vol 10; Flowering Plants), Eeudicots, Kubitzki, K.., (ed.), 56-71, Springer, ISBN 9783642143960, Berlin, Germany 
Devos, KM.; Brown, JKM.; Bennetzen, JL. (2002). Genome size reduction through illegitimate recombination counteracts genome expansion in Arabidopsis. Genome Research, Vol.12, No.7, (July 2007), pp. 1075-1079, ISSN 1088-9051

Dewitte, A.; Eeckhaut, T.; Van Huylenbroeck, J. \& Van Bockstaele, E. (2010a). Induction of unreduced pollen by trifluralin and $\mathrm{N}_{2} \mathrm{O}$ treatments. Euphytica, Vol.171, No.2, (October 2010), pp. 283-293, ISSN 0014-2336

Dewitte, A.; Eeckhaut, T.; Van Huylenbroeck, J. \& Van Bockstaele, E. (2010c). Meiotic aberrations during 2n pollen formation in Begonia. Heredity, Vol.104, No.2, (February 2010), pp. 215-223, ISSN 0018-067X

Dewitte, A.; Eeckhaut, T.; Van Huylenbroeck, J. \& Van Bockstaele, E. (2009b). Occurrence of viable unreduced pollen in a Begonia collection. Euphytica, Vol.168, No.1, (February 2009), pp. 81-94, ISSN 0014-2336

Dewitte, A.; Van Laere, K..; Van Huylenbroeck, J. \& Van Bockstaele, E. (2010b). Inheritance of $2 \mathrm{n}$ pollen formation in an F1 and F2 population of Begonia hybrids. Proceedings of the 23th international Eucarpia symposium, section colourful breeding and genetics Part II, ISBN 978-90-66051102, Leiden, The Netherlands, September 2010

Dewitte, A.; Leus, L.; Eeckhaut, T.; Vanstechelman, I.; Van Huylenbroeck, J. \& Van Bockstaele, E. (2009a). Genome size variation in Begonia. Genome, Vol.52, No.10, (October 2010), 829-838, ISSN 0831-2796

Doorenbos, J.; Sosef, M.; de Wilde, J. (1998). The sections of Begonia (Studies in Begoniaceae VI), Backhuys Publishers, ISBN 9057820072, Leiden, The Netherlands

Noor, MA.; Grams, KL.; Bertucci, LA. \& Reiland, J. (2001). Chromosomal inversions and the reproductive isolation of species. Proceedings of the National Academy of Sciences, Vol.98, No. 21 (October 2001), pp. 12084-12088, ISSN 0027-8424

Forest, LL.; Hughes, M. \& Hollingsworth, PM. (2005). A phylogeny from Begonia using nuclear ribosomal sequence data and morphological characters. Systematic Botany, Vol.30, No.3, (July 2005), pp. 671-682, ISSN 0363-6445

Forrest, LL. \& Hollingsworth, PM. (2003). A recircumscription of Begonia based on nuclear ribosomal sequences. Plant systematic and evolution., Vol.241, No.3-4, (November 2003), pp. 193-211, ISSN 0378-2697

Forrest, LL. (2001). Phylogeny of Begoniaceae, PhD theses. University of Glasgow, Glasgow.

Frodin, DG. (2004). History and concepts of big plant genera. Taxon, Vol.53, No.3, (August 2004), pp. 753-776, ISSN 0040-0262

Goodall-Copestake, W. (2005). Framework phylogenies for the Begoniaceae, PhD theses. University of Glasgow, Glasgow.

Goodall-Copestake, W.; Harris, DJ. \& Hollingsworth, PM. (2009). The origin of a megadiverse genus: dating Begonia (Begoniaceae) using alternative datasets, calibrations and relaxed clock methods. Botanical journal of the linnean society, Vol.159, No.3, (March 2009), pp. 363-380, ISSN 0024-4074

Goodall-Copestake, W.; Pérez-Espona, S.; Harris, DJ. \& Hollingsworth, PM. (2010). The early evolution of the mega-diverse genus Begonia (Begoniaceae) inferred from organelle DNA phylogenies. Biological journal of the linnean society, Vol.101, No.2, (October 2010), pp. 243-250, ISSN 0024-4074

Gross, BL. \& Rieseberg, LH. (2005). The ecological genetics of homoploid hybrid speciation. Journal of heredity, Vol.96, No.3, (May 2005), pp. 241-252, ISSN 0022-1503 
Gupta, RC.; Kumar, HP. \& Dhaliwal, RS. (2009). Cytological studies in some plants from cold desserts of India, Lahau and Spiti (Himachal Pradesh). Chromosome botany, Vol.4, No.1, (July 2009), pp. 5-11, ISSN 1881-5936

Haegeman, J. (1979). Tuberous Begonias. Origin and development. J. Cramer, ISBN 376821219X, Vaduz, Liechtenstein.

Harlan, J. \& De Wet, J. (1975). On Ö. Winge and a prayer: the origins of polyploidy. The botanical review, Vol.41, No.4, (October 2004), pp. 361-390, ISSN 0006-8101

Hoffmann, AA. \& Rieseberg, LH. (2008). Revisiting the impact of inversions in evolution: from population genetic markers to drivers of adaptive shifts and speciation. Annual review of ecology, evolution and systematics, Vol.39, (December 2008), pp. 2142, ISSN 1543-592X

Horn, W. (2004). The patterns of evolution and ornamental plant breeding. Proceedings of the 21 $1^{\text {st }}$ international Eucarpia symposium on classical versus molecular breeding of ornamentals Part II, ISBN 9789066056879, Munchen, Germany, August 2003

Hughes, M. \& Hollingsworth, PM. (2008). Population genetic divergence corresponds with species level biodiversity patterns in the large genus Begonia. Molecular ecology, Vol.17, No.11, (June 2008), pp. 2643-2651, ISSN 0962-1083

Hughes, M. (2008). An annotated checklist of Southeast Asian Begonia. Royal Botanic Garden Edinburgh, ISBN 9781906129149, Edinburgh, UK.

Hughes, M.; Hollingsworth, PM. \& Miller, AG. (2003). Population genetic structure in the endemic Begonia of the Socotra archipelago. Biological Conservation, Vol.113, No.2, (October 2003), pp. 277-284, ISSN 0006-3207

Hughes, NM.; Vogelmann, TC. \& Smith, WK. (2008). Optical effects of abaxial anthocyanin on absorption of red wavelengths by understorey species: revisiting the backscatter hypothesis. Journal of Experimental Botany, Vol.59, No.12, (September 2003), pp. 3435-3442, ISSN 0022-0957

Hvoslef-Eide, AK. \& Munster, C. (2007). Begonia. History and breeding. In: Flower Breeding and Genetics, chapter 9, Anderson, NO., (ed.), 241-275, Springer, ISBN 9781402044274, Dordrecht, The Netherlands

Kapoor, BM. (1966). IOPB chromosome number reports VIII. Taxon, Vol.15, No.7, (September 1966), pp. 279-284, ISSN 0040-0262

Keraudren-Aymonin, M. (1983). Begoniacees. In: Flore de Madagascar et des Comores, Leroy, JF., (ed.), 7-108, Museum national d'histoire naturelle, ISBN 2856541658, Paris, France

Kiew, R.; Teo, LL. \& Gan, YY. (2003). Assessment of the hybrid status of some Malesian plants using amplified fragment length polymorphism. Telopea, Vol.10, No.1, pp. 225-233, ISSN 0312-9764

Kubis, S.; Schmidt, T. \& Heslop-Harrison, JS. (1998). Repetitive DNA elements as a major component of plant genomes. Annals of Botany, Vol.82, Supplement I, (December 1998), pp. 45-55, ISSN 0305-7364

Legro, RAH. \& Doorenbos, J. (1969). Chromosome numbers in Begonia 1. Netherlands Journal of Agricultural Sciences, Vol.17, pp. 189-202, ISSN 0028-2928

Legro, RAH. \& Doorenbos, J. (1971). Chromosome numbers in Begonia 2. Netherlands Journal of Agricultural Sciences, Vol.19, pp. 176-183, ISSN 0028-2928 
Legro, RAH. \& Doorenbos, J. (1973). Chromosome numbers in Begonia 3. Netherlands Journal of Agricultural Sciences, Vol.21, pp. 167-170, ISSN 0028-2928

Legro, RAH. \& Haegeman, JFV. (1971). Chromosome numbers of tuberous begonias. Euphytica, Vol.20, No.1, (February 1971), pp. 1-13, ISSN 0014-2336

Leitch, I. \& Benett, M. (1997). Polyploidy in angiosperms. Trends in Plant Science, Vol. 2, No.12, (December 1997), pp. 470-476, ISSN 1360-1385

Levin, D. (1983). Polyploidy and novelty in flowering plants. American Naturalist, Vol.122, No.1, (July 1983), pp. 1-25, ISSN 0003-0147

Levy, AA. \& Feldman, M. (2002). The impact of polyploidy on grass genome evolution. Plant Physiology, Vol.130, No.4, (December 2002), pp. 1587-1593, ISSN 0032-0889

Lewis, W. (1980). Polyploidy in species populations. In: Polyploidy: biological relevance, Lewis, W., (ed.), 103-144, Plenum Press, ISBN 0306403587, New York

Lippman, ZB. \& Zamir, D. (2007). Heterosis: revisiting the magic. Trends in Genetics, Vol.23, No.2, (February 2007), pp. 60-66, ISSN 0168-9525

Long, M. (2001). Evolution of novel genes. Current opinion in genetics and development, Vol.11, No.6, (December 2001), pp. 673-680, ISSN 0959-437X

Long, M.; Betran, E.; Thornton, K. \& Wang, W. (2003). The origin of new genes: glimpses from the young and old. Genetics, Vol.4, (November 2003), pp. 865-875, ISSN 00166731

Mallet, J. (2007). Hybrid speciation. Nature Reviews, Vol.446, (March 2007), pp. 279-286, ISSN 1471-0056

Marasek-Ciolakowska; A., Ramanna, MS.; ter Laak, WA. \& Van Tuyl, JM. (2010). Genome composition of 'Elatior'-begonias hybrids analysed by genomic in situ hybridisation. Euphytica, Vol.171, No.2, (January 2010), pp. 273-282, ISSN 0014-2336

Matolweni, LO.; Balkwill, K. \& McLellan, T. (2000). Genetic diversity and gene flow in the morphologically variable, rare endemics Begonia dregei and Begonia Homonyma (Begoniaceae). American Journal of Botany, Vol.87, No.3, (March 2000), pp. 431-439, ISSN 0002-9122

Matsuura, H. \& Okuno, S. (1936). Cytogenetical studies on Begonia. The Japanese Journal of Genetics, Vol.12, No.1, pp. 42-43, ISSN 0021-504X

Matsuura, H. \& Okuno, S. (1943). Cytogenetical study in Begonia (Preliminary survey). Cytologia, Vol.13, No.1, (November 1943), pp. 1-18, ISSN 1348-7019

Matthews, ML. \& Endress, PK. (2004). Comparative floral structure and systematics in cucurbitales (Corynocarpaceae, Coriariaceae, Tetramelaceae, Datiscaceae, Begoniaceae, Cucurbitaceae, Anisophylleaceae). Botanical Journal of the Linnean Society, Vol.145, No.2, (June 2004), pp. 129-185, ISSN 0024-4074

McKenna, DD. \& Farrell, BD. (2006). Tropical forests are both evolutionary cradles and museums of leaf beetle diversity. Proceedings of the National Academy of Science, Vol.103, No.29, (July 2006), pp. 10947-10951, ISSN 0027-8424

Neale, S.; Goodall-Copestake, W. \& Kidner, CA. (2006). The evolution of diversity in Begonia. In: Floriculture, Ornamental and Plant Biotechnology, Teixeira da Silva, JA. (ed.), Global Science books, ISBN 4903313093, Middlesex, UK

Newman, LJ. (1966). Bridge and fragment aberrations in Podophyllum Peltatum. Genetics, Vol.53, No.1, (January 1966), pp. 55-63, ISSN 0016-6731 
Ng, PC. \& Kirkness EF. (2010). Whole Genome Sequencing. In: Genetic variation: methods and protocols 628 (Methods in Molecular Biology), Barnes, R. \& Breen, G., (Eds.), 215-226, Humana press, ISBN 1603273662, Totowa, NJ, US

Oginuma, K. \& Peng, CI. (2002). Karyomorphology of Taiwanese Begonia: taxonomic implications. Journal of Plant Research, Vol.115, No.3, (June 2002), pp. 225-235, ISSN 0918-9440

Okuno, S. \& Nagai, S. (1953). Cytological studies on Begonia evansiana Andr. with special reference to its meiotic chromosomes. The Japanese Journal of Genetics, Vol.28, No.4, pp. 132-136, ISSN 0021-504X

Okuno, S. \& Nagai, S. (1954). Karyotypic polymorphism in Begonia tuberhybrida. The Japanese Journal of Genetics, Vol.29, No.5-6, pp. 185-196, ISSN 0021-504X

Osborn, T.; Pires, J.; Birchler, J.; Auger, D.; Chen, Z.; Lee, H.; Comai, L.; Madlung, A.; Doerge, R.; Colot, V. \& Martienssen, R. (2003). Understanding mechanisms of novel gene expression in polyploids. Trends in Genetics, Vol.19, No.3, (March 2003), pp. 141-147, ISSN 0168-9525

Otto, SP. \& Whitton, J. (2000). Polyploid incidence and evolution. Annual Review of Genetics, Vol.34, pp. 401-437, ISSN 0066-4197

Paun, O.; Fay, MF.; Soltis, DE. \& Chase, MW. (2007). Genetic and epigenetic alterations after hybridization and genome doubling. Taxon, Vol.56, No.3, (August 2007), pp. 649656, ISSN 0040-0262

Paun, O.; Forest, F.; Fay, MF. \& Chase, MW. (2009). Hybrid speciation in angiosperms: parental divergence drives ploidy. New Phytologist, Vol.182, No.2, (February 2009), pp. 507-518, ISSN 0028-646X

Peng, C-I. \& KU, S-M. (2009). Begonia $\times$ chungii (Begoniaceae), a new natural hybrid in Taiwan. Botanical Studies, Vol.50, No.2, (April 2009), pp. 241-250, ISSN 1817-406X

Peng, C-I. \& Sue, C-Y. (2000). Begonia x taipeiensis (Begoniaceae), a new natural hybrid in Taiwan. Botanical Bulletin of the Academy Sinica, Vol.41, No.2, (April 2000), pp. 151158, ISSN 0006-8063

Peng, C-I.; Liu, Y.; Ku, S-M.; Kono Y. \& Chung, K-F. (2010). Begonia $\times$ breviscapa (Begoniaceae), a new intersectional natural hybrid from limestone areas in Guangxi, China. Botanical Studies, Vol.51, No.1, (January 2010), pp. 107-117, ISSN 1817-406X

Pinheiro, F.; De Barros, F.; Palma-Silva, C.; Meyer, D.; Fay, MF.; Suzuki , RM.; Lexer, C. \& Cozzolino, S. (2010). Hybridization and introgression across different ploidy levels in the Neotropical orchids Epidendrum fulgens and E. puniceoluteum (Orchidaceae). Molecular Ecology, Vol.19, No.18, (September 2010), pp. 3981-3894, ISSN 0962-1083

Plana, V. (2003). Phylogenetic relationships of the Afro-Malagasy members of the large genus Begonia inferred from trnL Intron sequences. Systematic botany, Vol.28, No.4, (October 2003), pp. 693-704, ISSN 0363-6445

Plana, V.; Gascoine, A.; Forest, LL.; Harris, D. \& Pennington, RT. (2004). Pleistocene and prepleistocene Begonia speciation in Africa. Molecular Phylogenetics and Evolution, Vol.31, No.2 (May 2004), pp. 449-461, ISSN 1055-7903

Rajbhandary, S. (2010). Systematic revision of the genus Begonia L. (Begoniaceae) in the Himalayas, PhD theses. Tribhuvan University, Kathmandu, Nepal. 
Ramanna, MS. \& Jacobsen, E. (2003). Relevance of sexual polyploidization for crop improvement-a review. Euphytica, Vol.133, No.1, (July 2003), pp. 3-18, ISSN 00142336

Ramsey, J \& Schemske, DW. (1998). Pathways, mechanisms and rates of polyploidy formation in the flowering plants. Annual Review of Ecology and Systematics, Vol.29, (November 1998), pp. 267-501, ISSN 0066-4162

Renner, SS. (2005). Relaxed molecular clocks for dating historical plant dispersal events. Trends in Plant Science, Vol.10, No.11, (November 2005), pp. 550-558, ISSN 1360-1385

Rieseberg, H. \& Carney, S. (1998). Tansley review 102: Plant hybridization. New Phytologist, Vol.140, No.4, (December 1998), pp. 599-624, ISSN 0028-646X

Rubite, RR. (2010). Systematic studies on Philippine Begonia L. section Diploclinium (Lindl.) A. D.C. (Begoniaceae), PhD theses. De La Salle University, Manila

Sanmiguel, P. \& Bennetzen, JL. (1998). Evidence that a recent increase in maize genome size was caused by the massive amplification of intergene retrotransposons. Annals of Botany, Vol.82, Supplement 1, (December 1998), pp. 37-44, ISSN 0305-7364

Schaefer, H. \& Renner, SS. (2011). Phylogenetic relationships in the order Cucurbitales and a new classification of the gourd family (Cucurbitaceae). Taxon, Vol.60, No.1, (February 2011), pp. 122-138, ISSN 0040-0262

Shui, YM.; Peng, CI. \& Wu, CY. (2002). Synopsis of the Chinese species of Begonia (Begoniaceae), with a reappraisal of sectional delimitation. Botanical Bulletin of Academia Sinica, Vol.43, No.4, (October, 2002), pp. 313-327, ISSN 0006-8063

Sosef, MSM. (1994). Refuge begonias. Taxonomy, phylogeny and historical biogeography of Begonia sect. Loasibegonia and sect. Scutobegonia in relation to glacial rain forest refuges in Africa, $\mathrm{PhD}$ theses. Wageningen Agricultural University, ISBN 9054852437, Wageningen, The Netherlands

Stults, DZ. \& Axsmith, BJ. (2011). First macrofossil record of Begonia (Begoniaceae). American Journal of Botany, Vol.98, No.1, (January 2011), pp. 150-153, ISSN 0002-9122

Taylor, SJ.; Arnold, M. \& Martin, NH. (2009). The genetic architecture of reproductive isolation in Louisiana irises: hybrid fitness in nature. Evolution, Vol.63, No.10, (October 2009), pp. 2581-2594, ISSN 1558-5646

Tebbitt, MC. (2005). Begonias: cultivation, identification and natural history. Timberpress, ISBN 0881927333, Portland, USA.

Tebbitt, MC.; Lowe-Forrest, LL.; Santoriello, A.; Clement, WL. \& Swensen, SM. (2006). Phylogenetic relationships of Asian Begonia, with an emphasis on the evolution of rain-ballist and animal dispersal mechanisms in sections Platycentrum, Sphenanthera and Leprosae. Systematic botany, Vol.31, No.2, (April 2006), pp. 327-336, ISSN 03636445

Teo, L-L. \& Kiew, R. (1999). First record of a natural Begonia hybrid in Malaysia. Garden Bulletin of Singapore, Vol.51, No.1, pp. 103-118, ISSN 0374-7859

Thomas, DC. 2010. Phylogenetics and historical biogeography of Southeast Asian Begonia L. (Begoniaceae), PhD theses. University of Glasgow, Glasgow.

Thomas, DC.; Hughes, M.; Phutthai, T.; Rajbhandary, S.; Rubite, R.; Ardi, W.H. \& Richardson, J.E. (2011). A non-coding plastid DNA phylogeny of Asian Begonia (Begoniaceae): Evidence for morphological homoplasy and sectional polyphyly. 
Molecular Phylogenetics and Evolution, Vol. 60, No. 3, (September 2011), pp. 428-444, ISSN 1055-7903

Tobe, H. \& Raven, PH. (1987). Systematic embryology of the Anisophylleaceae. Annals of the Missouri botanical garden, Vol.74, No.1, pp. 1-26, ISSN 0026-6493

Twyford, AD. \& Ennos, RA. (2011). Next generation hybridization and introgression. Heredity, doi: 10.1038/hdy.2011.68., ISSN 0018-067X

Zeng Z-B. (2005). QTL mapping and the genetic basis of adaptation: recent developments. Genetica, Vol.123, No.1-2, (February 2005), pp. 25-37, ISSN 0016-6707

Zhang, L-B.; Simmons MP.; ocyan, A. \& Renner SS. (2006). Phylogeny of the Cucurbitales based on DNA sequences of nine loci from three genomes: Implications for morphological and sexual system evolution. Molecular Phylogenetics and evolution, Vol.39, No.2, (May 2006), pp. 305-322, ISSN 1055-7903 


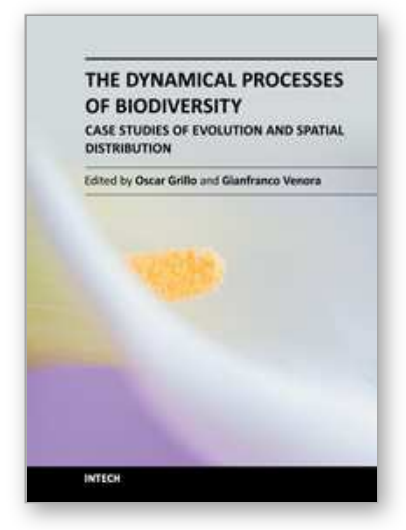

\author{
The Dynamical Processes of Biodiversity - Case Studies of \\ Evolution and Spatial Distribution \\ Edited by PhD. Oscar Grillo
}

ISBN 978-953-307-772-7

Hard cover, 366 pages

Publisher InTech

Published online 02, December, 2011

Published in print edition December, 2011

Driven by the increasing necessity to define the biological diversity frame of widespread, endemic and threatened species, as well as by the stimulating chance to describe new species, the study of the evolutive and spatial dynamics is in constant execution. Systematic overviews, biogeographic and phylogenic backgrounds, species composition and distribution in restricted areas are focal topics of the 15 interesting independent chapters collected in this book, chosen to offer to the reader an overall view of the present condition in which our planet is.

\title{
How to reference
}

In order to correctly reference this scholarly work, feel free to copy and paste the following:

A. Dewitte, A.D. Twyford, D.C. Thomas, C.A. Kidner and J. Van Huylenbroeck (2011). The Origin of Diversity in Begonia: Genome Dynamism, Population Processes and Phylogenetic Patterns, The Dynamical Processes of Biodiversity - Case Studies of Evolution and Spatial Distribution, PhD. Oscar Grillo (Ed.), ISBN: 978-953-307772-7, InTech, Available from: http://www.intechopen.com/books/the-dynamical-processes-of-biodiversitycase-studies-of-evolution-and-spatial-distribution/the-origin-of-diversity-in-begonia-genome-dynamismpopulation-processes-and-phylogenetic-patterns

\section{INTECH}

open science | open minds

\section{InTech Europe}

University Campus STeP Ri

Slavka Krautzeka 83/A

51000 Rijeka, Croatia

Phone: +385 (51) 770447

Fax: +385 (51) 686166

www.intechopen.com

\section{InTech China}

Unit 405, Office Block, Hotel Equatorial Shanghai

No.65, Yan An Road (West), Shanghai, 200040, China

中国上海市延安西路65号上海国际贵都大饭店办公楼405单元

Phone: $+86-21-62489820$

Fax: +86-21-62489821 
(C) 2011 The Author(s). Licensee IntechOpen. This is an open access article distributed under the terms of the Creative Commons Attribution 3.0 License, which permits unrestricted use, distribution, and reproduction in any medium, provided the original work is properly cited. 